İşletme Akademisi Dergisi
$2020,1(3): 261-274$
DOI: $10.26677 / T R 1010.2020 .545$
Dergi web sayfasi: www.isakder.org

Araștırma Makalesi

\title{
Covid-19 Pandemisi Döneminde Özel ve Yabancı Sermayeli Bankalarda Alınan Önlemler
}

\author{
Dr. Hale Nur GÜLER \\ halgu76@gmail.com, www.orcid.org/0000-0002-6333-1849
}

Öz

2019 yılında ilk olarak Çin'in Wuhan eyaletinde görülen 2020 yılında ise dünyada olduğu gibi Türkiye' dede gündemi önemli şekilde belirleyen COVID-19 pandemisi sebebi ile pek çok sektör etkilenmiştir. Bu süreçte kurumlar hem müşterileri hem de çalışanları için ürün ve hizmet süreçlerinde birtakım değişikliklere gitmişlerdir. Finansal piyasalarda önemli aracılık görevi yapan bankaların aldıkları önlemler hem ekonomik hem müşterilerin ve çalışanların sağlığı açısından oldukça kritiktir. Bu kapsamda Türkiye' deki özel ve yabancı sermayeli bankaların aldıkları önlemler incelenmiştir. Pandemi sürecinde bankaların aldıkları önlemler arasında müşterilerini işlemleri için dijital kanallara ağırlıklı olarak yönlendirdikleri görülmektedir. ATM'lerden işlem yapma limitlerinin artırıldığı, kartla temassız ödeme limitlerinin yükseltildiği, dijital kanallardan yapılan para gönderme işlemlerinin ücretsiz şekilde yapılması, ekonomik destek paketi olarak kredili ürünler için borç erteleme taleplerine yanıt verildiği görülmektedir. Bankaların şube çalışma saatlerine sınırlama getirdiği, genel müdürlük ve şube çalışanlarının dönüşümlü ve olabildiğinde uzaktan erişim modeli ile çalıştırıldığı, eğitim, toplantı gibi etkinlikleri uzaktan video konferans ile yaptıkları ifade edilmektedir. Bankalar bu süreçte kronik hasta hamile personellerine idari izin kullandırmaktadır. Bankaların çalışanlarının ihtiyaç duyduğu maske eldiven gibi ürünleri temin ettiği de belirtilmektedir.

Anahtar Kelimeler: Korona Virüsü (COVID-19), Bankacllık Sektörü, Pandemi, Müşteri ve Çalışan Deneyimi, Stratejik Yönetim

Makale Gönderme Tarihi: 19.06.2020

Makale Kabul Tarihi: 30.08 .2020

\section{Önerilen Atıf:}

Güler, H. N. (2020). Covid-19 Pandemisi Döneminde Özel ve Yabancı Sermayeli Bankalarda Alınan Önlemler, İşletme Akademisi Dergisi, 1(3): 261-274.

(C) 2020 İşletme Akademisi Dergisi. 


Journal of Business Academy
$2020,1(3): 261-274$
DOI:10.26677/TR1010.2020.545
Web pages: www.isakder.org

$\underline{\text { Research Article }}$

\title{
Measures Taken in Private and Foreign Capital Banks During the Covid-19 Pandemic Period
}

\author{
Dr. Hale Nur GÜLER \\ halgu76@gmail.com, www.orcid.org/0000-0002-6333-1849
}

\begin{abstract}
As first seen in 2019 in Wuhan province in China in 2020 while the world as it is in Turkey was also affected many sectors of the agenda significantly in determining the cause of pandemics Covidien-19. In this process, organizations have made some changes in their product and service processes for both their customers and employees. The measures taken by banks, which act as important intermediaries in financial markets, are very critical both for the economy and for the health of customers and employees. In this context, Turkey's private and measures taken by foreign-owned banks have been examined. It is seen that among the measures taken by banks during the pandemic process, they predominantly direct their customers to digital channels for their transactions. It is seen that the limits of making transactions from ATMs, contactless payment limits with cards were increased, free money sending transactions made through digital channels, and debt deferral requests for credit products as an economic support package were responded. It is stated that banks impose restrictions on branch working hours, headquarters and branch employees are employed alternately and, whenever possible, with remote access models, and they conduct activities such as training and meetings via remote video conferencing. Banks grant administrative leave to chronically ill pregnant personnel in this process. It is also stated that banks provide products such as mask and gloves that their employees need.
\end{abstract}

Keywords: Corona Virus (COVID-19), Banking Industry, Pandemic, Customer and Employee Experience, Strategic Management

Received: 19.06 .2020

Accepted: 30.08 .2020

\section{SuggestedCitation:}

Güler, H. N. (2020). Measures Taken in Private and Foreign Capital Banks During the Covid-19 Pandemic Period, Journal of Business Academy, 1(3): 261-274.

(C) 2020 Journal of Business Academy. 


\section{GİRİ̧̧}

Koronavirüs (Covid-19) ilk defa Aralık 2019' da Çin'in Wuhan eyaleti ile başlamış olup ateş öksürük nefes darlığı gibi solunum yolları belirtileri ile gelişmiş olup tüm dünyayı etkisi altına almıştır. Dünya Sağlık Örgütü 11 Mart 2020 itibariyle yüzondört ülkede yüzonsekizbin vakanın görülmesi ve dört bin ikiyüzdoksanbir kişinin hayatını kaybettiğini açıklayarak koronavirüsü pandemi olarak ilan etti (BBC, 2020). Pandemi salgının belirli bir bölgeyi aşarak büyük bir kitleyi ve neredeyse bütün insanlığı etkilemesi olarak belirtilmektedir (Meriam-Webster, 2020). Küresel olarak gelişen pandemi, sağlığın yanı sıra sosyal, mesleki, politik, ekonomik, etik ve ahlaki sonuçlara yol açmakta olup salgına karşı gecikme ve karmaşa yaşanması sebebi ile pandemi olarak dönüşüm oluşagelmiştir (Vander Weele T. J. vd. 2020: 189).

Koronavirüs salgını halkın sağlığını tehdit ettiği için pek çok hükümet ekonomik faaliyetleri sınırlayarak sağlık açısından oluşan tehditi önlemeye çalışmaktadır (Kraemer vd. 2020: 25). Pek çok ülkede ekonomik faaliyetlerin azalması hatta durma noktasına geldiği pandemi sürecinde hükümetler, işletmeleri ve hane halklarını desteklemek için mali, parasal ve düzenleyici tedbirler dahil olmak üzere büyük programlar başlatmışlardır (Andersen vd., 2020: 2).

Tüm dünyayı etkilediği gibi Türkiye'de de ekonomik ve sosyal faaliyetlerin düzenlenmesi, acil durum mekanizmalarının hazır tutulması, hastanelerin risk sebebi ile hazırlanması, tespit, izolasyon, test ve tedavi uygulama araç ve yöntemlerinin hazırlanması süreçleri işletilmektedir. Pandemi nedeni ile pek çok sektör olumsuz etkilenmektedir (Macit ve Macit, 2020: 113). Bankaların ekonomik piyasalarda aracılık faaliyetleri sebebi ile önemi büyüktür. Bankalar mevduat toplayarak ihtiyacı olan bireysel ve kurumsal müşterilerine vermektedir.

Bankalar müşterilerine pek çok ürün ve hizmet sunmaktadır. Bu ürün ve hizmetler kredi işlemleri yapmak, parayı muhafaza etmek, para transferi, çek senet işlemleri, kefalet teminat referans mektubu hazırlayıp sunmak, kiralık kasa hizmeti vermek, ödemeler ve kart işlemleri olarak belirtilebilir. Bankalar işlevlerini yaparken regülasyonlar yasal düzenlemeler, müşteri beklentileri, çalışan beklentileri, karlılık rekabet üstünlüğü gibi pek çok kritik faktörü göz önünde bulundurmaktadır.

Bankaların faaliyetleri sırasında teknolojik gelişmeler ve üstün insan kaynağı süreçlerine yardımcı olmaktadır. Bankalar teknolojinin değişmesi dijitalleşme süreçlerini özenle takip etmektedir. Pandemi sürecinde bankalar ağırlıklı olarak dijital kanallardan işlemlerin yapılması için müşterilerini yönlendirmekte, mobil bankacilık internet bankacılığı çağrı merkezi ve ATM'ler ile hizmetleri sunmaya devam etmektedirler. Ülkemizde 10 Mart 2020 ile koronavirüs vakasının tespit edilmesinin ardından diğer sektörlerde olduğu gibi bankacılık sektöründe de bankaların aldıkları önlemler hem müşteriler hem çalışanlar, ekonomi ve toplum sağlığ açısından oldukça kritik yer teşkil etmektedir.

Toplum sağlı̆̆ının ve ekonominin istikrarı için müşteri beklentilerinin etkin şekilde anlaşılması, yasal regülasyonlar çerçevesinde ürün ve hizmetlerin uyarlanması ve önlemlerin buna göre şekillendirilmesi gerekmektedir. Pandemi döneminde yaşanan müşteri deneyimi sonraki dönemler için bankalar açısından müşteri kazanımı ya da kaybına yol açabilecektir. Diğer yandan piyasaların beklentilerinin karşılanabilmesi için kredili ürünlerin sunumu ve süreçleri de bankaların en önemli faaliyetleri arasındadır. Ürün ve hizmet sunumlarında bankaların pandemi 
döneminde esnek yönetim anlayışlarını da ortaya koymaktadır. Müşterilere sunulacak ürün ve hizmetlerin yeterliliği sunulan kanalların etkinliği çalışanlara sağlanan kolaylıklar onlar için alınan sağlık tedbirleri sürdürülen eğitimlerin etkinliği ve başarısı pek çok iyileşmeye sebep olabilecektir.

Bankaların uygulamalarının müşterinin deneyimi iyileştirmesi ve hizmet kesintisini engelleme yönündedir. Dijital kanalların etkin şekilde kullanılması, müşteri bilgilendirmelerinin zamanında ve eksiksiz yapılabilmesi, Sağlık Bakanlığı tarafından belirlenen yüksek riskli yaş grubundaki müşterilere özel ürün ve hizmetlerde süreçlerin değiştirilip esnetilmesi bu dönemde başarı kriterleri arasında sayılmaktadır.

Diğer yandan çalışanların da kendileri aileleri sağlık açısından korunmalı beklenilen bilgilendirmeler şeffaf açık ve zamanında yapılmalıdır. Finans piyasalarında bankalar oldukça önemli şekilde aracılık rolü üstlenmektedir. Bankaların faaliyetlerinin ekonomiye yansımaları oldukça önemlidir. Küresel salgının kurumlara ve ekonomiye etkilerini mümkün olduğunca sınırlı ölçüde tutabilmek için bankaların hem müşterileri hem de çalışanları için aldıkları önlemlerin bilinmesi kritiktir.

Bu salgın ve sonraki dönemler için alınan önlemlerin ekonomik faaliyetler açısından bilinirliği hem kurumlar hem yöneticiler hem de çalışanlar için örnek teşkil edecektir. Bu sebeple çalışmada aşağıdaki soruya yanıt aranmıştır:

- Türkiye' de bankaların Covid-19 pandemisi için aldıkları önlem ve uygulama değişiklikleri nelerdir?

Bankaların müşterileri ve çalışanları için aldıkları önlemlerin çeşitleri ve bilinirliği bankacılık sektörü ile ilgilenen yönetici çalışan ve araştırmacılara yön gösterici olacağı düşünülmektedir.

\section{COVID-19 PANDEMİSI SÜRECİ VE BANKALARIN UYGULAMALARI}

Epidemi, belirli bir bölgede bir hastalığın salgın haline gelmesi, pandemi salgının belirli bir bölge dışında büyük çoğunluktaki kitleyi etkileyerek insanlığa karı tehdit oluşturması anlamına gelmektedir (Aslan, 2020: 35). Koronavirüs (Covid-19) ilk defa Çin'deki Wuhan eyaletinde Aralık 2019 döneminde solunum yollarındaki ateş öksürükle ve nefes darlı̆̆1 gibi belirtiler veren hastalar için yapılan araştırmaların sonucunda 13 Ocak 2020'de tanımlanan virüstür.

Sağlık Bakanlığı'nın paylaşmış olduğu 26 Mayıs 2020 tarihli verilerine göre ülkemizdeki vaka sayısının 157.814 toplam vefat sayısının ise 4.329 olduğu belirtilmiştir. Bakanlık tarafından virüsün bulaşmasının engellenebilmesi için vatandaşların evde kalmaları ve sosyal mesafe kuralına uymaları maske ve eldiven kullanmaları önerilmiştir (Sağlık Bakanlığı, 2020).

190 'dan daha fazla ülkeyi etkileyerek 25 ülkede de ölüm oranlarının yüksekliği sebebi ile virüs dünya gündeminde birinci sırada bulunmaktadır (Gilbert, vd. 2020: 871). 26 Mayıs 2020 tarihi itibari ile Dünya Sağlık Örgütü'nün paylaştığı bilgilere göre virüsün dünya üzerindeki yaygınlığına Resim 1' de yer verilmiştir. 
Resim 1: COVID-19 Pandemisinin Dünya' daki Dağılımı

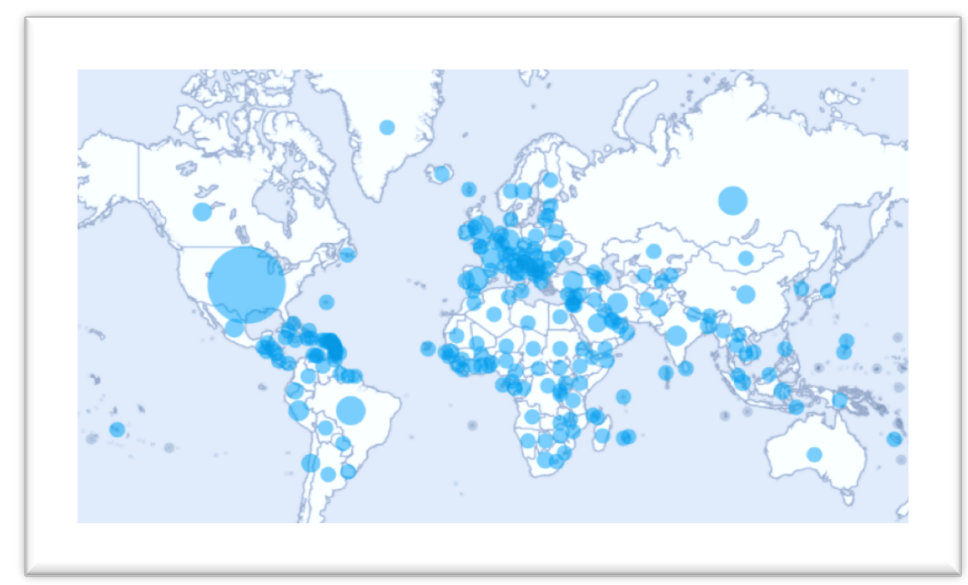

Kaynak: DSÖ, 2020

Dünyadaki vakaların sayısı 5.304 .772 ve vefat eden kişi sayısı 342.029 olarak ve 216 ülkede virüsün görüldüğ̈̈ belirtilmiştir. Tablo $1^{\prime}$ de bölgelerin vaka sayısı ve vefat sayıları gösterilmektedir.

Tablo 1. Dünya Üzerinde Bölgesel Vaka ve Vefat adetleri

\begin{tabular}{|r|c|c|} 
& Toplam vaka adeti & Vefat adeti \\
\hline Bölgeler & 5.304 .772 & 342.029 \\
\hline Afrika & 80.002 & 2.120 \\
\hline Amerika & 2.395 .295 & 141.472 \\
\hline Doğu Akdeniz & 427.832 & 11.164 \\
\hline Avrupa & 2.025 .176 & 174.429 \\
\hline Güneydoğu Asya & 201.207 & 5.952 \\
\hline Batı Pasifik & 174.548 & 6.879 \\
\hline
\end{tabular}

Kaynak: DSÖ, 2020

Koronavirüsün Türkiye' de tespit edilmesinin ardından iş ve sosyal hayatta belirli tedbirler alınmakta, virüsün bulaş riski azaltılmaya çalışılmaktadır. Bankacılık sektörü de hem toplum sağlığı hem de ekonomik açıdan oldukça önemli bir sektör olup aldıkları tedbirler doğrudan insani ve ekonomik süreçlere etki etmektedir. Bankalar gerek Sağlık Bakanlığı' nın belirlediği kurallar gerekse Bankacılık Düzenleme ve Denetleme Kurumu (BDDK)' nın yapmış olduğu bazı düzenlemelerle hizmet ve uygulamalarında değişikliğe gitmektedir. Yapılan değişiklikler ve yenilikler hem müşterileri hem çalışanları etkilemektedir.

Müşterilerin pandemi döneminde beklentilerinin öngörülmesi oluşabilecek şikayetler açısından da önemlidir. Bankalar her dönemde eski müşterileri elde tutabilmek ve yeni müşteri kazanabilmek için beklentileri dikkatle karşılamalıdır (Hakiri, 2012: 25). Müşterilerin beklentilerinin yerine getirilmemesi veya eksik şekilde ya da hatalı şekilde yapılması şikayetin doğmasına yol açmaktadır (Chébat, Davidow ve Codjovi, 2005: 15). Müşterilerce iletilen olumsuz bildirimler, bankaların ürün ve hizmet kalitesini değiştirip geliştirme çabaları için 1şık tutacak gibi görünmekle beraber ekonomik ve sağlık anlamında içinde bulunduğumuz olumsuz pandemi döneminde müşterilerin duygusal yoğunluğunun da yüksek olduğu düşünülerek uzun 
vadede olumsuz sonuçlar doğmaması açısından belirli önlemlerin alınmasını gerektirmektedir (Güler, 2020: 86).

Bankalar misyonlarınca piyasalarda fon sağlayıp ihtiyacı olan bireysel ve kurumsal müşterilerine iletmekte ve paranın transfer edilmesi, kredi kartı hizmetleri, para saklama, çek senet uygulamaları, kefalet teminat referans mektubun düzenlenmesi, kiralık kasa uygulamaları gibi pek çok çeşit hizmet sunmaktadır. Bankaların finansal piyasalardan doğan fon arz ve talebini karşılayarak önemli aracılık görevleri bulunmaktadır (Çağlar ve Uslu, 2012). Bu kapsamda bankaların işlemleri ile piyasa ödünç verilebilecek fonun arz ve talebi ile genişleyerek milli gelir ve istihdam olanağı artmaktadır. Bu faydalarına ilave olarak bankaların yönettikleri fonların ilgili ve yararlı ekonomik sahalara aktarılması etkin bankacılık kurguları ve uygulamaları ile yönetilen para politikası sayesinde ülkenin iç ve dış ekonomik ilişkileri açısında fayda sağlayacak dünya ile entegre şekilde etkin ve verimli seviyeye ulaşılabilecektir (Arslan ve Yaprakl1, 2008: 30).

Pandemi döneminde bankaların aldıkları tedbirler sundukları ürün ve hizmetler kadar hizmet verilen kanalların seçimi de oldukça önemlidir. Müşteri deneyiminin 1980'li yıllarda tüketici davranışlarının geleneksel ve deneyimsel olarak iki farklı yaklaşımla ayrılmaları ile karşımıza çıkmıştır. Müşterilerin markalar ile bağ kurarken yaşam tarzları ile uyumu ve daha önce yaşanılan deneyimleri ile süreci şekillendirmek oldukları bilinmektedir (Çiçek, 2015: 39). Kurumlar karlılıklarını ve beklentilerini karşılayarak değişim ve gelişimi yakından takip edip müşteriler ile uzun dönemli ilişkiler kurmayı hedeflemektedirler. Bu amaçla en iyi müşteri deneyimini tasarlamak için çalışmaktadırlar. Deneyim üzüntü, mutluluk, sevme ve sevilme, acı çekmek, kazanma ve kaybetme gibi birçok insani değerin tecrübe edildiği yaşamı ifade etmektedir (Batı, 2017: 40). Akıllı müşteri deneyiminin (AMÜD) tasarlanması, sürdürülmesi ve gelişim ve değişim içinde olması hem kurum yöneticileri hem de çalışanlar tarafından önemle ve özenle ele alınması gereken kritik konular arasındandır.

Pandemi döneminde müşterilerin içinde bulundukları ekonomik ve sosyal koşullar nedeni ile beklentilerinde de değişiklikler yaşanmaktadır. Bir yandan yasal düzenlemeler bir yandan idari düzenlemeler nedeni ile müşterilerin bankalara rahatlıkla erişimini sağlayacak uygun çözümler getirilmelidir. Ekonomik açıdan yaşanan değişiklikler, belirli yaş grubunun sokağa çıkmasının kısıtlanması gibi uygulamalar nedeni ile müşteri beklentilerinde değişiklik yaşanmıştır. Bankaların müşterilerine sundukları çeşitli krediler örneğin, İhtiyaç, konut, taşıt, motosiklet, tekne kredisi, alışveriş gibi krediler, ek hesap uygulamaları, kredi kartı, banka kartı, sanal kart, mevduat ve yatırım ürünleri (vadeli mevduat, yatırım fonları, döviz, altın ürünleri, tahvil, bono, repo, türev ürünleri, VIOP, Varant, kaldıraçlı FX işlemleri gibi), ödemeler ve hizmet uygulamaları (fatura ve kira ödemeleri, emekli maş ödemeleri, bağış ödemeleri, seyahat çeki tahsilatları, otoyol ve köprü ödemeleri, şans oyunları ödemeleri, kiralık kasa hizmetleri) gibi çok sayıda ürün ve hizmet sağlayarak müşterileri ile iletişim halinde olmaları gerekmektedir. Bankalar ürün ve hizmetlerini müşterilere ulaştırırken çok çeşitli kanallar kullanmaktadır. Bu kanallardan bazıları şube, telefon, web sitesi, twitter, instagram, facebook gibi sosyal medya kanalları, ATM (Automatic Teller Machine) kiosk ve whatsup uygulamasıdır.

Önceki dönemlerde sadece şubeler aracılığı ile hizmetlerine devam eden bankalar teknolojideki değişimler ve alt yapının oluşturulması ile müşteri beklentileri ve karlılık gözetilerek dijital 
kanallara dönüşmektedir. Pek çok işlemin dijital kanallardan yapılabildiği günümüzde pandemi döneminde de çeşitli esneklikler sağlanarak müşterilerin bu kanalları kullanmaları beklenmektedir. Diğer yandan çalışanların da etkin şekilde sağlıklarının korunması hem fiziksel hem psikolojik açıdan bankalarca sağlanmaya çalışılmaktadır. Sağlık Bakanlığının tavsiyeleri üzerine pandemi ile mücadelede kapalı alanlardaki zemin ve yüzeyler sıklıkla temizlenmeli, para ile temas eden kişilerin el temizliğine özen göstermeleri sağlanmalıdır. Şubelerde bulunan numaratörlerin sadece bir kişi tarafından kullanılması önerilmektedir. Herhangi bir solunum sıkıntısı olan çalışan şikayetleri düzelene kadar çalıştırılmamalıdır. Maske kullanılmalıdır. Şubelerde bekleme alanında sosyal mesafeye dikkat edilmelidir. Çalışanlarda eğitimler verilmelidir (Sağlık Bakanlığı, 2020).

Bankacılıkta önceki dönemlerde müşterilerine şubeler kanalı ile hizmet vermekte iken bugün gelinen teknolojik açılımlar ile müşterilerin ihtiyaçlarının temini internet, mobil ve çağrı merkezi gibi kanalları ile gerçekleştirilmektedir. İçinde bulunulan pandemi koşulları altında bankaların müşterilerini daha çok alternatif kanallara yönlendirdiği bilinmektedir. Müşterilerin işlemleri için oluşturulan ürün ve hizmet kanallarının geniş ağı zaman ve verimlilik sağlamaktadır. Bankaların çeşitli düzenlemeler ve talepler neticesinde kurguladıkları işlem süreç ve uygulamaları hem müşteriler hem çalışanlar hem de diğer paydaşlar için olumlu sonuçları amaçlamaktadır.

\section{YÖNTEM}

Çalışma nitel olarak tasarlanmış ve doküman incelemesi yapılmıştır. Nitel araştırmalarda gözlemler, görüşmeler, doküman analizleri şeklinde veriler edilmektedir (Yıldırım ve Şimşek, 2008: 39). Nitel araştırmalarda toplumsal benliğin kabulü, bir bakış açısının benimsenerek, çalışmanın tasarlanması, verilerin toplanması, analiz edilmesi, yorumlanması ve bilgilendirme şeklindeki süreçler bulunmaktadır (Neuman, 2012: 23).

Nitel araştırmalar için verilere kitap, dergi, makale, anket gibi yazılı ve görsel kaynaklardan ulaşılmaktadır (Baş ve Akturan, 2008: 118; Coffey ve Atkinson, 1996: 101). Nitel araştırmalar için yapılan doküman incelemesinde incelenen konuyu içeren olgu ve olaylar hakkında bilgi veren yazılı belgelerin analiz edilmesi ifade edilmektedir. $\mathrm{Bu}$ inceleme methodunun faydası araştırmacıya zaman kazandırması olarak belirtilmektedir (Yıldırım ve Şimşek, 2008: 188).

Nitel araştırmalar betimsel ve içerik analizi şeklinde tasarlanmaktadır (Yıldırım ve Şimşek, 2008: 223). Betimsel analiz çeşitli veri toplama yöntemleri ile ulaşılan verilerin daha önceden belirlenmiş olan temalara göre özetlenip yorum yapılması şeklinde ifade edilmektedir (Yıldırım ve Şimşek, 2003: 105). İçerik analizi de elde edilen verilerin kategorik olarak sınıflandırılması, konu kelime grupları yapılarak sunulmasıdır (Silverman, 2001: 85). Croswell nitel araştırmalarda veri analizinin her araştırmanın doğası gereği sahip olması gereken özellikleri nedeni ile kendi amacına uygun veri analiz planı geliştirilmesine ihtiyaç duyduğunu belirtmiştir (Croswell, 2003: 190). Çalışmada betimsel analiz yapılmış olup elde edilen veriler belirli bir çerçevede belirli bir ilişki içinde aktarılmıştır. Araştırmanın veri toplama ve değerlendirme diyagramı Şekil $1^{\prime}$ de gösterilmiştir. 


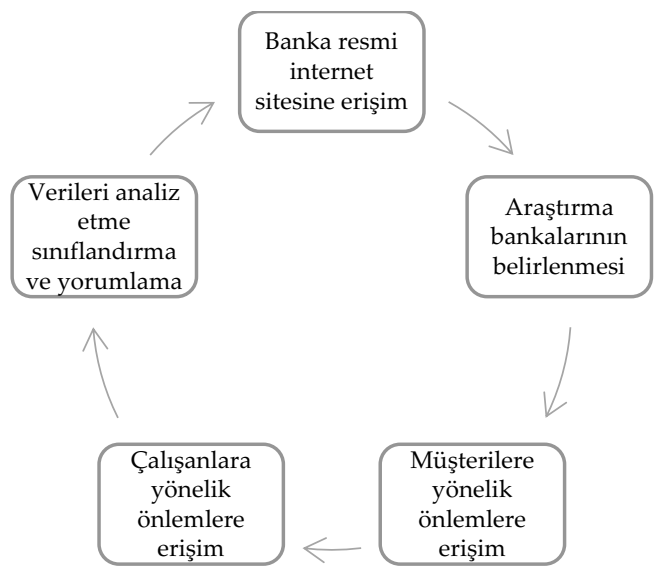

Şekil 1. Araştırmanın Veri Toplama ve Değerlendirme Diyagramı

Türkiye Bankalar Birliği'nden elde edilen bilgilere göre Türkiye'de faaliyetlerini sürdürmekte olan kırk sekiz banka bulunmaktadır. Çalışmada özel ve yabancı sermayeli bankalardan çalışan sayısı yüksekliği bakımından ilk on banka arasında yer alan beş bankanın aldığı önlemler incelenmiştir (TBB, 2020). Bankalar belirlenirken Covid 19 pandemisi nedeniyle hem müşteri hem çalışan bakımından alınan önlemler için kapsamlı şekilde bilgi veren bankalardan beş tanesi araştırmaya dahil edilmiştir. Türkiye Bankalar Birliği verilerine göre araştırmaya dahil edilen bankalara aşağıda Tablo 2' de yer verilmiştir.

Tablo 2. Araştırmaya Dahil Edilen Bankalar

\begin{tabular}{|r|l|} 
Tür (Sermayesine Göre) & \multicolumn{1}{c}{ Banka } \\
Özel & Türkiye İş Bankası A.Ş. \\
Yabancı & QNB Finansbank A.Ş. \\
Özel & Türk Ekonomi Bankası A.Ş. \\
Özel & Şekerbank T. A.Ş. \\
Yabancı & HSBC Bank A.Ş.
\end{tabular}

Kaynak: TBB, 2020

Araştırmada hem müşterileri hem de çalışanları için kapsamlı bilgiyi resmi internet sayfaları üzerinden paylaşan bankaların verileri kullanılmıştır. Önlem olarak uygulamaya aldıkları halde internet sitesinde paylaşılmayan süreç değişiklikleri ya da geliştirmeler araştırma kapsamına alınamamıştır.

\section{BULGULAR}

Bankaların müşteriler ve çalışanlar açısından aldıkları önlem ve uygulamalar aşağıdaki gibidir. Araştırmaya dahil edilen banklardan olan İş Bankası' nın ekonomiye destek paketi adı altında firmaların ve gerçek kişiler için vadesi gelen borçları için erteleme, istihdamı düşürmeme şartına bağlı olarak KOBİ ve mikro işletmeler için ödeme yapılandırması, maaş müşterileri için ek limit tahsis edilmesi şeklinde uygulamalar sunduğu belirtilmiştir. Sağlığı korumak için dijital bankacılık kanallarından yapılacak olan bankalar arası ve banka içi para transferi işlemlerinden ücret ve komisyon alınmayacağı ifade edilmiştir(İş Bankası, 2020).

İş Bankası maaşı düşük olan çalışanlarını koruyarak enflasyon beklentisinin ötesinde zam yapmış olup zam oranların 500 TL'nin altında olmayacak şekli ile kademeli olarak \%16-\%14-\%11 olarak 
belirtmiştir. 14 günlük dönüşüm şeklinde $\% 50$ ve yaklaşık 9000 kişinin online olarak evden çalışmasını ve yaklaşık 5000 kişinin evde kalmasını sağlamıştır. Çalışanlarından hamile, kronik hasta, süt emzirenlere idari izin kullandırmıştır. Çalışanlarından okul çağında çocuğu olanlara da talebe göre ücretli ya da ücretsiz izin verilmiştir. Yapılan işin gereği iş yerine gelen ve dönüşümlü çalışmaya dahil olamayan çalışanlara ve yöneticilere aylık 3.500 TL brüt ödeme yapılmasını kararlaştırılmıştır. Çalışanlarda hijyen koşullarına rahat uyum amacı ile serbest kıyafet uygulamasına geçilmiştir. Şubelerde görev yapan çalışanlara ihtiyaç duydukları maske eldiven dezenfektan temini yapılmış olup para ile teması olanlara da eldiven kullanımı zorunlu kılınmıştır. Genel müdürlük binasında toplu yemek yerine çalışanların masalarına kumanya dağıtımı yapılmıştır. Kumanya uygulaması gözetim altında hazırlanmak şartı ile yapılmıştır. Genel müdürlük ve operasyon merkezleri için termal kamera ile izleme yapılmıştır. Havalimanında, üniversitelerde, hastanelerde ve AVM şubelerinde çalışmalara son verilmiştir. Tüm bina ve lokasyonlarda dezenfekte sıklıkla yapılmıştır. Bankamatik cihazlarında ve çalışanların kullandıkları servislerde detaylı temizlik sıklığı artırılmıştır. Havalandırma sistemlerinde dezenfekte çalışmaları artırılmıştır. Yurt içinde yurt dışında yapılacak olan tüm etkinlikler geçici süre ile durdurulmuş, toplantılar video konferans ile yapılmıştır. Çalışanlardan ya da yakınlarından yurtdışından dönenler için 14 gün işe gelinmemesi istenmiştir. Yaşanılan süreç içinde çalışanlar ve müşterilere sürekli bilgi akışı sağlanmış olup çalışanlar sağlık uzmanlarının ve kurumda görevli doktorların hazırladıkları video klipler ile bilgilendirilmiştir (İş Bankası, 2020).

QNB Finansbank' ta şubelerin çalışma saatleri 12:00-17:00 olarak salgın döneminin yoğun olduğu zamanlarda belirlenmiştir. Şubelerdeki bekleme alanlarına kontrollü sayıda müşteri alınmaktadır. Müşterilere alternatif bankacılık kanallarını ve ATM'leri kullanmaları önerilmektedir. Müşterilerin şubelerde maske takmaları gerektiği belirtilmiştir. Çağrı Merkezinin çalışma saatleri ve iletişim numaraları müşterilere hatırlatılmıştır. Günlük para çekme limit ATM için 5.000 TL şeklinde düzenlenmiş olup temassız kart şifresi ile işlem limiti de 120 TL' den 250 TL' ye çıkartılmıştır. 5.000 TL' nin altındaki meblağların para yatırma çekme kredi kartı ödemesi kredi ödemesi işlemleri sadece ATM'lerden gerçekleştirilmektedir. Pandemiden dönemsel olarak etkilenen sektörler için tüzel müşterilerden nakit akışında problem yaşayanlara 6 ay ile 1 yıl ödemesiz olacak şekilde yapılandırma alternatifi sunulmuş ve bu başvuruların Çağrı Merkezi'nden yapılabileceği iletilmiştir. Para transferlerinin şubeye gidilmesine gerek kalmadan Cep Şubesinden İnternet Şubesinden ve ATM'lerden yapılacak havale ve EFT işlemlerinden ücret alınmayacaktır. Tek ATM Platformu, QNB Finansbank ATM'lerine ilave Deniz Bank ve TEB ATM' leri de hesaptan para çekme, hesaba para yatırma ve kredi kartı borç ödeme işlemlerinde ücretsiz şekilde kullanılabilmiştir. Müşteriler hesap bakiyesi sorgulama, kredi kartı borcu sorgulama ve limit bilgisi sorgulama işlemlerini de sınırsız sayıda ücretsiz yapabilmişler bu yönde bilgilendirilmişlerdir. Tüm ATM' lerin temizliği için dezenfektan kullanımına başlanmıştır. Hastane, havalimanı, otogar gibi yoğun kullanılan yerlerdeki ATM'lerin temizlik sıklığı artırılmıştır (QNB Finansbank, 2020).

QNB Finans Bank' ta çalışanlar için hastalıktan korunma yolları, hijyen çalışmaları konusunda düzenli olarak bilgilendirmeler yapılmıştır. E-eğitimlerle bilgi akışı sağlanmaktadır. Pandeminin ilk döneminden itibaren acil ve zorunlu sebepler dışında yurtdışına iş için çıkışlar 
durdurulmuştur. Çalışanların yurt dişı seyahatleri, eğitim, müşteri ziyareti seminer gibi ziyaretleri iptal edilmiştir. Yurtdışına çıkanların dönüş tarihinden itibaren 14 gün boyunca işe gelmeleri engellenmiştir. Çalışanların çoğu uzaktan erişim şeklindeki modelle mesailerini evden sürdürmektedir. Tüm çalışanlar arasında bulunan hamile ve kronik rahatsızlığı olanlara idari izin verilmiştir. Çocuğu olup bakacak kimsesi olmayan çalışanlardan izin isteyenlere izin verilmiştir. Banka içi eğitimler ertelenmiş olup toplantılar uzaktan erişim ile yapılmaktadır. Tüm çalışma alanlarında sık periyodlarla hijyen çalışmaları yapılmakta ve gerekli olan alanlara temizlik ve hijyen ürünleri yerleştirilmiştir. Şube çalışanlarına eldiven ve maske temini sağlanmıştır. Aynı anda kullanımları olan yemekhane ve ortak alanların faaliyetleri kontrollü yapılmakta ve spor salonu kullanımı durdurulmuştur. Şubelerde ihtiyaç kadar çalışan bulundurulmasına dikkat edilmektedir (QNB Finansbank, 2020).

Türk Ekonomi Bankası'nda tüm çalışma alanları belirli gün ve aralıklarla dezenfekte edilmektedir. Şubelerin çalışma saatleri 12:00-17:00 olarak belirlenmiştir. Şube içindeki bekleme alanları düzenli olarak hijyenik malzemelerle temizlenmektedir. Şubelerde güvenlik görevlileri yoğunluğu engellemek için belirli bir sıra ile müşterileri içeri almaktadır. ATM'lerin temizliği uzun süre kalıcı özelliği olan dezenfektanlarla sağlanmaktadır. Hastane yakını gibi riskli olan ve nüfusun yoğun olduğu bölgelerdeki temizlik sıklığı artırılmıştır. Günlük para çekme limiti ATM'lerde geçici olarak 3.000 TL olmuş ve kartlı ödeme temassız işlem limiti 250 TL olarak belirlenmiştir. Alışverişlerde önce banka kartı veya kredi kartı mümkünse temassız ödeme yapmaları müşterilere önerilmektedir. Üye işyerleri POS cihazlarının dezenfektanlarla temizlenmesi yönünde uyarılmaktadır. Banka müşterilerini işlemleri için mobil bankacılık, internet bankacılığı ve ATM'leri kullanmaları yönünde bilgilendirmektedir (Türk Ekonomi Bankası, 2020).

Şeker Bank çalışanların kendilerini virüse karşı nasıl koruyabileceklerine yönelik farkındalıklarını yükseltecek iletişim ve eğitim uygulamaları yapmıştır. Hizmet verilen alanlar için virüs salgınından koruyucu temel malzemeler temin edilmiştir. Binalar, hizmet alanları ve ATM' ler sık periyodlarla dezenfekte edilmektedir. Şube çalışma saatleri 10:00-17: 00 olarak belirlenmiştir. Sağlık Bakanlığı tarafından belirlenen risk grubundaki çalışanlar ve büyük bir kısım çalışan evden çalışma modeli ile hizmet vermektedir. Şube çalışanları için dönüşümlü çalışma modeline geçilmiştir.

Müşteri ziyaretleri, toplantılar durdurularak telekonferans ve video konferans platformu kullanılmıştır. Şubelerde yoğunluk oluşmaması için müşterilere belirli sayıda ve sırada hizmet verilmektedir. Müşterilerin dijital kanallara yönlendirilmesi sağlanmakta işlemlerin çağrı merkezi, mobil bankacılık, internet bankacılığı ve ATM'lerden yapılması önerilmektedir. Bu kanallardan yapılacak EFT ve havale işlemleri için ücret alınmamaktadır. Müşteriler şube dışındaki kanallardan yapabilecekleri işlemler için bilgilendirilmektedir. Bankada kredi ürünlerinin ve kredi kartlarının borçlarının ertelenmesi için ekonomiye destek paketi de sunulmaktadır (Şeker Bank, 2020).

HSBC Bank' ta müşterilere dijital kanallardan işlem yapmaları önerilmekte ve yapılabilecek işlemler için bilgilendirmeler ve videolar sunulmaktadır. İnternet ve mobil bankacılık şifresini nasıl alabilecekleri belirtilmiştir. Mobil bankacılık, internet bankacılığı, telefon bankacılığı ve 
ATM'lerden yapılacak EFT ve havale işlemleri ücretsiz olacaktır. Nakit ihtiyacı için ATM'lerden günlük para çekme limiti kart çeşitlerine göre artırılmıştır. Diğer banka ATM'lerinden yapılacak nakit çekme işlemleri de ücretsizdir. Bulunan lokasyona göre bazı şubeler haftanın sadece üç günü müşteri ziyaretine açık olacaktır.

Şubelere aynı anda belirli sayıda müşteri alınacaktır. Çalışanların büyük bir kısmı evden çalışmaktadır. Seyahat kısıtlamaları yapılmış olup riskli bölgelerden dönen çalışanların kişisel karantina uygulaması yapılmaktadır, çalışanlar pandemi için düzenli olarak bilgilendirilmektedir (HSBC Bank, 2020).

\section{TARTIŞMA SONUÇ VE ÖNERILER}

İlk olarak Çin'de görülen solunum yolu ile kısa sürede büyük kitleleri etkisi altına alarak hasta edebilecek düzeyde etkileyen virüs nedeni ile pandemi ilan edilen süreçte bankacıllk sektöründe alınan önlemlerin belirlenmesine yönelik yapılan bu çalışmada Türkiye'deki özel ve yabancı sermayeli çalışan sayısı fazla olan beş bankanın müşterileri ve çalışanlarını korumaya yönelik aldıkları önlemler ve uygulama değişiklikleriele alınmıştır. Bankalarınpandemi döneminde aldıkları önlem ve gidilen uygulama değişikliklerine resmi internet sitelerinden ulaşılmıştır.

Aralık 2019’ un sonunda başlayarak ülkemiz ve dünya için önemi çok büyük olan koronavirüsü dolayısı ile pek çok sektörde ekonomik faaliyet açısından gerileme hatta durma noktasına gelindiği bu özel ve kritik günlerde bankaların müşterilerini hem korumak hem fayda sağlamak için Bankacılık Düzenleme ve Denetleme Kurumu'nun, Sağlık Bakanlığı'nın ve diğer tüm yasal ve idari yönlendirmeler ve kendi kurum politikaları kapsamında oluşturdukları müşteri deneyimi yaratan uygulamaları ve hizmetleri oldukça kritik önem taşımaktadır. Bankaların finansal piyasalarda ekonominin ileriye doğru ilerleyebilmesi için önemli aracı kurumlar olarak görev yaptıkları ifade edilmektedir. Fiyatlama, hizmet sunum şekli, hizmet verilen kanallar açısından bankaların aldıkları önlemler hem müşterilerin bugünleri atlatmasında hem de gelecek için çalışacakları bankalara karar vermeleri açısından çok kritiktir. Bankaların müşterileri gibi aynı zamanda çalışanları açısından yarattıkları süreçler de çalışan deneyiminin farklılaştırılması için önemlidir. Çalışanların bu süreçte hem fiziksel hem de ruhsal olarak psikolojilerinin yönetilmesi onlar için önemlidir.

Çalışmada bankalar ekonomiye destek paketi olarak gerçek ve tüzel kişilerin borçlarının ertelenmesini sağlamışlar ve borçlar için yeniden yapılandırılmaya gidilmiştir. Bankalar bireysel ve tüzel müşterilerinden ihtiyaç duyanlar için anapara faiz ve taksit ödemelerinde mevcut koşullarla öteleme imkanı sunmuşlardır. Müşterilerini dijital kanallar olan mobil bankacılık, internet bankacılığı, çağrı merkezleri ve ATM'lerden işlem yapmaları için yönlendirmişlerdir. Bununla birlikte dijital kanallardan yapılan EFT havale işlemlerinden ücret alınmamaktadır. ATM'lerde günlük para çekme limitleri, kart ile temassız işlem yapma limiti artırılmıştır. Şubelerin, ATM'lerin dezenfekte işlemlerinde sıklık sağlanmıştır. Yoğun kullanılan yerlerde bulunan ATM'lerin temizliği daha sık yapılmıştır.

Çalışan deneyimi açısından banka uygulamalarına bakıldığında ise bankalardan çalışanlarına maaş zammı yapanlar olmuştur. Hamile süt izni kullanan Sağlık Bakanlığınca belirlenen kronik hastalığı olan çalışanlara idari izin kullandırılmıştır. Okul çağında çocuğu olup bakacak kimsesi olmayan çalışanlardan ihtiyaç duyanlara izin verilmiştir. Çalışanlara hijyen koşullarını rahatça 
sağlayabilmeleri için serbest kıyafet uygulaması getirilmiştir. Genel müdürlük şube diğer çalışma alanlarındaki çalışanlara maske eldiven dezenfektan temini yapılmıştır. Havalimanı, üniversite, hastane ve AVM şubeleri kapatılmıştır. Yurt içinde ve yurt dışında yapılması planlanan tüm toplantı ve etkinlikler ertelenmiş olup eğitimler videolarla yapılmaktadır. Süreçte çalışanların kendilerini pandemiye karşı koruma yöntemleri için sürekli eğitim ve bilgilendirilmeler yapılmaktadır. Yurtdışından dönen çalışanların 14 gün süre ile işe gelmemeleri sağlanmıştır. Bankalar çalışanlarının büyük bir kısmı uzaktan erişim modeli ile evden çalışma ve dönüşümlü çalışmalarına teknolojik alt yapı çalışmalarını sağlayarak hazır hale getirmişlerdir. Şube çalışma saatlerinde değişiklik yapılmış olup şubede çalışma süresi düşürülmüştür. Şubelerde yoğunluk oluşmaması ve sosyal mesafenin korunabilmesi için belirli sayıda müşteri sıra ile içeri alınmaktadır.

Araştırmadan elde edilen verilere göre bankaların müşterilerini işlemleri için şubeler dijital kanallara yönlendirildiği görülmektedir. Bu dönemde dijital okur yazarlık oldukça önemlidir. Müşterilerin dijital kanallardan işlemlerini ne şekilde kolaylıkla yapabilecekleri dijital kanal üyeliklerini ne şekilde başlatabilecekleri ile ilgili bilgilendirici mesajlar ya da eğitimlerle desteklenmeli bu desteğin yaş eğitim gibi belirli kriterlere göre ayrıştırılmasının faydalı olacağı tartışılmalıdır.

Alınan idari kararlar kapsamında sokağa çıkma yaş aralığında olan altmış beş yaş üstü ve yirmi yaş altındaki müşterilere yönelik alınan önlemlerle ilgili detay bilgilere sayfalarda rastlanamamıştır. Bilgiye kolay erişimin sağlanabilmesi için örneğin bu yaş grubundaki müşterilerin ihtiyaç duyabilecekleri para çekme yatırma gibi en temel faaliyetleri nasıl yapabileceklerine ve dijital kanal üyeliklerini ne şekilde aktif edebileceklerine ilişkin bilgilerin verilmesinin yararlı olacağı düşünülmektedir.

Bankaların pandemiye ilişkin aldıkları önlemlerin internet sayfalarında ne derece güncel şekilde bilgilendirilmesinin yapıldığı bilinmemektedir. Dolayısı ile bilgi güncelliğine dikkat edilecek şekilde bilgi paylaşımı yapılmalıdır. Uygulamaların devam edip etmediğine ilişkin yazılan metinlerden bilgi sahibi olunamamaktadır. Diğer yandan alınan önlemler internet sayfalarında ana sayfada yer almayan bankalar da vardır. Bankaların bu dönemde bilgilere erişimi kolaylaştırıcı tedbirler almaları tavsiye niteliğinde ifade edilebilir. Etkili müşteri deneyimlerinin yaratılması için bilgilendirmeler ve etkin uygulamalar oldukça yararlıdır. Bankaların aldıkları tüm önlemlerin bilinirliğinin sağlanması için sitelerinde güncel şekilde yer alması yararlı olacaktır.

Çalışanlar için evden çalışma uygulamasında ne kadar çalışanın bu uygulamaya dahil edildiği paylaşılmamıştır. Alt yapı eksikliği sebebi ile dahil olamayan çalışanların olması durumu yaşanıyor ise teknolojik gelişimlerin her banka tarafından dikkatle hayata geçirilmesi beklenmektedir. Bankaların çalışanları için pandemiyle mücadele sırasında hijyene, ruhsal ya da fiziksel birliği korumaya yönelik eğitimlerin her bankada olmadığı görülmektedir. Bankaların çalışanları için eğitim ve motivasyon sağlayıcı faaliyetlerin uygulamalarının sağlanması ya da yapılıyorsa da bu kapsamda alınan önlemler bilgilendirmelerinde yer verilmesi uygun olacaktır. Diğer yandan dijital kanallara yönlendirilen müşterilerin çağrı merkezlerinde yaratacağ yoğunluk sebebi ile bekleme sürelerinin optimum seviyede tutulabilmesi için personel desteği ya 
da çalışma koşulları konusunda bankalar bilgi paylaşımına gitmemiştir. Bankaların aldıkları önlemler tüm sektörler açısından ekonomiyi şekillendirecektir.

Çalışmadaki veriler bankaların ilan ettikleri ile sınırlıdır. Bundan sonraki araştırmacıların yurtdışındaki bankaları da dahil ederek uygulamaları değerlendirmeleri gerek bankacılık sektörü uygulamaları gerekse müşteri ve çalışan deneyimi iyileştirmeleri açısından faydalı olabilecektir. Çalışmanın pandemi döneminde bankacılık, müşteri deneyimi ve çalışan deneyimi ile ilgilenen araştırmacılara yararlı olacağı düşünülmektedir.

\section{KAYNAKÇA}

Andersen, A.L, Hansen, E.T., Johannesen, N. and Sheridan, A. (2020). Responses To The Covid19 Crises: Evidence From Bank Acount Transaction Data, Cebi Working Paper Series, 130.

Aslan, R. (2020). Tarihten Günümüze Epidemiler, Pandemiler ve Covid-19, Ayrıntı Dergisi, 8 (65): 35-41.

Arslan, İ. ve Yapraklı, S. (2008). Banka Kredileri ve Enflasyon Arasındaki İlişki: Türkiye Üzerine Ekonometrik Bir Analiz (1983-2007), Ekonometri ve İstatistik, (7), 89.

Baş, T. ve Akturan, U. (2008). Nitel Araştırma Yöntemleri NVivo 7.0 ile Nitel Veri Analizi, Ankara, Seçkin Yayıncılık.

Batı, U. (2017). Markethink Ya Da Farkething: Deneyimsel Pazarlama ve Duyusal Markalama, 1.Bask1, İstanbul: Kitap Kulübü, 40.

BBC (2020), https://www.bbc.com/turkce/haberler-dunya-51614548 (Erişim Tarihi: 16.08.2020).

Chébat, J., C., Davidow, M. ve Codjovi, I. (2005). "Silent Voices, Why Some Dissatisfied Consumers Fail To Complain", Journal of Service Research, 7 (4), 1-15.

Coffey, A. ve Atkinson, P. (1996) Making Sense Of Qualitative Data: Complementary Research Strategies, Newbury Park, CA: Sage. 101-131.

Creswell, J. W. (2003). Research Design: Qualitative, Quantitative, And Mixed Methods Approaches. California: Sage Publications.

Çağlar, N. ve Uslu, I. (2012). Para ve Banka, Anadolu Üniversitesi Yayınları, Yayın No: 2667, 14.

Çiçek, B. (2015). “Deneyimsel Pazarlama ve Satın Alma Karar Sürecine Etkisi: Termal Turizm Sektöründe Bir Uygulama", (Yayınlanmamış Yüksek Lisans Tezi, Bozok Üniversitesi SBE, 39.

Gilbert, M., Pullano, G., Pinotti, F., Valdano, E., Poletto, C., Boëlle, P. Y., and Gutierrez, B. (2020). Preparedness And Vulnerability of African Countries Against Importations of COVID19: A Modelling Study. The Lancet, 395 (10227), 871-877.

Güler, H.N. (2020). Koronavirüsü (COVID-19) Günlerinde Bankalara İletilen Müşteri İtiraz ve Şikayetlerinin İncelenmesi, 7 (4), 85-99.

Hakiri, W. (2012). For An Efficient Complaints Management System For Banks: A Conceptual Frame Work and an Exploratory Study, Journal Of Marketing Research \& Case Sudies. 
HSBC Bank, 2020: https://www.hsbc.com.tr/haberler/koronavirus-salgini-kapsamindaaldigimiz-onlemler, (Erişim Tarihi: 16.05.2020).

İş Bankası (2020). https://www.isbank.com.tr/bankamizi-taniyin/genel-mudurumuz-adnanbalinin-koronavirus-onlemlerine-iliskin-aciklamalari, (Erişim Tarihi: 16.05.2020).

Kraemer, M. U., Yang, C. H., Gutierrez, B., Wu, C. H., Klein, B., Pigott, D.M., du Plessis, L., Faria, N. R., Li, R., Hanage, W.P., Brownstein, J. S. (2020). “The Effect of Human Mobility and Control Measures on the COVID-19 Epidemic in China." Science, 25-45.

Macit, A. ve Macit, D. (2020). Türk Sivil Havacıllk Sektöründe Covid-19 Pandemisinin Yönetimi, Avrasya Sosyal ve Ekonomi Araştırmaları Derneği (ASEAD), 7(4), 100-116.

Merriam-Webster. (2020). When Does an Outbreak Become an Epidemic? https://www.merriamwebster.com/words-at-play/spanish-flu, (Erişim Tarihi: 16.08.2020).

Neuman, W. L. (2012). Toplumsal Araştırma Yöntemleri: Nicel ve Nitel Yaklaşımlar I-II. Cilt (5.Basım), İstanbul: Yayın Odası, 23-43.

Sağlık Bakanlığı (2020). https://www.saglik.gov.tr, (Erişim Tarihi: 16.05.2020).

Sağlık Bakanlığı (2020). https://covid19.saglik.gov.tr/, (Erişim Tarihi: 16-17.05.2020).

Silverman, D. (2001). Interpreting Qualitative Data: Methods for Analysing Talk, Text and Interaction. London: SAGE Publication.

Türkiye Bankalar Birliği (TBB) (2020). https://www.tbb.org.tr/tr/bankacilik/arastirma-veyayinlar/infografikler/infografik:-bankacilik-sektorunce-alinan-koronavirus-onlem-veuygulamalari/4505, (Erişim Tarihi: 16.05.2020).

Şeker Bank, 2020, https://www.sekerbank.com.tr/hakkimizda/krnbilgilendirme, (Erişim Tarihi: 16.05.2020).

Türk Ekonomi Bankası (TEB), 2020. https://www.teb.com.tr/haberler/sagliginizi-onemsiyoruzduyuru/, (Erişim Tarihi: 16.05.2020)

QNB Finansbank, 2020, https://www.qnbfinansbank.com/korona-virus-salginina-karsibankamizca-alinan-tedbirler, ${ }_{,}$(Erişim Tarihi: 16.05.2020).

Vander Weele T. J. Chen Y. Long K. Kim E. S. Trudel-Fitzgerald C. Kubzansky L.D. (2020). Positive Epidemiology? Epidemiology 31(2), 189-192.

Yıldırım, A., Şimşek, H. (2003). Sosyal Bilimlerde Nitel Araştırma Yöntemleri. Ankara: Seçkin Yayınları.

Yıldırım, A. ve Şimşek, H. (2008). Sosyal Bilimlerde Nitel Araştırma Yöntemleri (6.Baskı), Ankara: Seçkin Yayıncılık. 